\title{
Comparative Study on the Effect of Diverse Substrates on the IN scIE
Cultivation of Pleurotus ostreatus (Jacq.) P. Kumm. (Oyster Mushroom)
}

\author{
Tolulope S. Ewekeye ${ }^{1 *}$, Aisha \\ 1,2,3,4, Department of Botany, Faculty of \\ Science, Lagos State University, Nigeria
}

\section{Correspondence}

Tolulope Ewekeye, Department of Botany, Faculty of Science, Lagos State University, Nigeria.

Email:tolulope.ewekeye@lasu.edu.ng

Telephone: $+234(0) 8028783539$

\section{O. Ogungbade ${ }^{2}$, Adetayo A. Sanni ${ }^{3}$ and Oyedamola A. Oke}

Abstract:

Introduction: Pleurotus ostreatus (Oyster mushroom) is an eatable mushroom with an exceptional aroma and savour. It is suited to be cultivated in temperate as well as tropical climate.

Aims: This research was aimed at comparing the effects of different substrates on the cultivation of $P$. ostreatus.

Materials and Methods: The substrates used in this study were cornhusk, sawdust with wood shavings, banana leaves and a combination of all the substrates. All substrates bags were inoculated with $52.5 \mathrm{~mL}$ teaspoon of spawn, autoclaved at $121^{\circ} \mathrm{C}$ and $1.1 \mathrm{~kg} / \mathrm{cm}^{2}$ pressure and incubated under appropriate conditions both at the cropping room and fruiting chambers. The linear mycelia growth and biological efficiency were determined.

Results: The time for spawn running varied between 20-60 days and harvesting took between 60-85 days. The maximum linear mycelia growth after spawn running, were observed on cornhusk and the longest mycelia growth time (60 days) was observed on sawdust after spawn running. The highest yield of $P$. ostreatus was obtained in cornhusk treatments with an average weight value of $92.1 \mathrm{~g}$ while the banana leaves treatment gave no yield at all. The yield for combination of all substrates was $23 \mathrm{~g}$ and $22.3 \mathrm{~g}$ was obtained on sawdust. The highest biological efficiency of $67.03 \%$ was obtained on cornhusk and the lowest $(16.23 \%)$ was obtained on sawdust.

Conclusion: Among all the substrates, cornhusk was established as the most effective substrate for the production of $P$. ostreatus as it best supported both the spawn running phase and the yield phase.

Keywords: Cornhusk, Cultivation, Pleurotus ostreatus, Spawn running, Substrates

All co-authors agreed to have their names listed as authors.

This is an open access article under the terms of the Creative Commons Attribution License, which permits use, distribution and reproduction in any medium, provided the original work is properly cited.

(C) 2018 The Authors. Journal of Research and Reviews in Science - JRRS, A Publication of Lagos State University 


\section{INTRODUCTION)}

There has been heightened production of Pleurotus species usually referred to as oyster mushroom across the globe through the last couple of decades $[1,2]$. In 1997, species of Pleurotus produced 14.2 per cent of the entire eatable mushroom. $P$. ostreatus plays a major role in the management of organic wastes which has become an issue because of the challenge of disposal [3]. In developing countries around the world, malnourishment is a concern. Due to their taste, texture, nutritive values and high productiveness per unit area, mushrooms have been recognised as an outstanding food supply for alleviating malnourishment in these countries [4].

The nutritional value is one of the reasons why mushrooms are readily embraced and taken in place of meat. Generally, eatable mushrooms contents have less fat and calories, high vitamin B and C contents, have higher protein than a few other plant-based foods and likewise provide suitable supply of mineral nutrients [5]. $P$. ostreatus is a common edible mushroom; it was cultivated in Germany as a subsistence measure during world war and is now grown commercially around the world for food [6]. Worldwide, they are next to button mushroom in terms of popularity [7].

Cornhusk, sawdust, hull, straw, stalk wastepaper, leaves and sugarcane residues can be used as substrates to promote mushroom growth. Most cultivated mushrooms can be grown on various dead organic materials and agricultural wastes. The materials used depend on what is readily available [8]. $P$. ostreatus is well suited for cultivation in the temperate as well as the tropic climates; it is grown and harvested throughout the year [9]. Oyster mushroom can be grown on a wide variety of substrates [10]. The aim of this research was to compare the effect of different substrates on the cultivation of $P$. ostreatus.

\section{MATERIAL AND METHODS}

Collection of samples: The substrates used for the investigation were sawdust, wood shavings, dry banana leaves, and cornhusk. Sawdust and wood shavings were both collected at Ipaye sawmill, along LASU-Isheri Expressway, Lagos State, dry banana leaves were collected at Homes and Design gardens, LASU-Isheri Expressway, Lagos State and cornhusk were collected from corn farm opposite Lagos State University, Post Service Bus stop. Calcium was purchased at Lagos State Farm settlement Agric, along Lagos-Badagry Express, Lagos State while the spawn of $P$. ostreatus was obtained from Prudent Organic Farm, Odongunyan Ikorodu, Lagos State.

\section{Preparation of substrates}

The substrates were soaked in water for few minutes and air-dried on clean and well disinfected laboratory benches to remove excess moisture.
The banana leaves and the cornhusk were shredded to pieces of about $1 \mathrm{~cm}$ length and dried for two weeks alongside the sawdust and wood shavings. After drying; the sawdust and wood shavings were distributed evenly into planting plastics and irrigated with 1.2 litres of water and mixed thoroughly. The same procedure was used for the banana leaves, cornhusk as well as the fourth treatment which was a combination of sawdust, wood shavings, cornhusk and banana leaves in equal proportion. Six hundred gram of Calcium (powdery form) was added to reduce the $\mathrm{pH}$ content of all the substrates, according to the modified method of [11].

All treatments were subjected to the same climatic conditions: temperature, photoperiod and relative humidity $(50-60 \%)$. One thousand gram of each substrate was weighed and packed in polythene bags of $50 \mathrm{~cm} \times 23 \mathrm{~cm}$ in size with three replicates each and was sterilised in an autoclave at $121^{\circ} \mathrm{C}$ and 1.1 $\mathrm{kg} / \mathrm{cm}^{2}$ pressure for thirty minutes.

The treatments in this study include:

$$
\begin{aligned}
& \mathrm{SD}=\text { Sawdust }+ \text { wood shavings }+ \text { Calcium }+\mathrm{H}_{2} \mathrm{O} \\
& \mathrm{BL}=\text { Banana leaves }+ \text { Calcium }+\mathrm{H}_{2} \mathrm{O} \\
& \mathrm{CH}=\text { Cornhusk }+ \text { Calcium }+\mathrm{H}_{2} \mathrm{O} \\
& \mathrm{CB}=\text { Combination of } \mathrm{SD}+\mathrm{BL}+\mathrm{CH}+\text { Calcium }+\mathrm{H}_{2} \mathrm{O}
\end{aligned}
$$

Spawning of bags: The spawn of $P$. ostreatus was used for its effective cultivation. After sterilisation, the treatments were all allowed to cool overnight and inoculated the following morning. All the substrates (treatments) and replications were then inoculated with $52.5 \mathrm{~mL}$ of spawn in each bag [11].

Linear mycelia growth: The linear growth was determined by measuring the length from the top of each treatment bag to the point where the spawn was showing a whitish colour (an indication of colonization). The assessment of the mycelia growth on the substrates was recorded every five day till the sixtieth day.

Time for conclusion of spawn running: Time was documented in days for the conclusion of growth of mycelium on substrates in all bags.

Yield and biological efficiency: The overall mass of all fruiting bodies produced on all the substrates were calculated as entire yield of mushroom and the average mean value for all substrates was determined. The Biological Efficiency (BE) was computed using the formula of [12];

B.E. $(\%)=$ Fresh weight of mushroom $(g) \times 100 \%$

Dry weight of substrates $(\mathrm{g})$

Average mean value $=$ Total sum up value

Total number 


\section{Statistical analysis}

Data were computed using SPSS version 20. Analyses was done using t-test while the level of significance was at $95 \%$ confidence interval $(p=0.05)$

\section{RESULTS AND DISCUSSION}

Cornhusk took 25 days to complete its spawn running phase with the mean mycelial growth length of $19.33 \pm 5.13 \mathrm{~cm}$. The banana leaves took 30 days to complete its spawn running phase with mean mycelial length of $18.50 \pm 2.00 \mathrm{~cm}$. There was no significant difference $(p>0.05)$ in the phases of spawn running on Cornhusk and banana leaves on days 5 and 25 while there was a significant difference $(p<0.05)$ on days 10 , 15, 20 and 30 (Table 1a). The spawn running on the combination of the substrates (CB) started on the $15^{\text {th }}$ day while that of Sawdust (SD) started on the $40^{\text {th }}$ day from inoculating day. It took 60 days to complete the spawn running on $\mathrm{SD}$. For $\mathrm{CB}$, the mean mycelia length of $22.00 \pm 15.00 \mathrm{~cm}$ was recorded on the $35^{\text {th }}$ day. Except for days 5 and 10, there was significant difference $(p<0.05)$ in the phases of spawn running on the combined substrates and sawdust throughout the 60 days (Table $1 b$ ).

It is evident from the result that the maximum mean linear mycelia growth was observed on sawdust $(22 \pm 0.00 \mathrm{~cm})$ on the $60^{\text {th }}$ day however, the fastest mycelia growth $(19.33 \pm 5.13 \mathrm{~cm})$ was recorded on cornhusk after 25 days of incubation. Cornhusk showed the fastest completion of $P$. ostreatus spawn running with 25 days of complete colonization of the bags.

From this study, the maximum yield was obtained from cornhusk with an average mean value of $33.53 \pm 13.70$ g. The lowest average yield was obtained from sawdust $(22.30 \pm 0.00)$ and the banana leaves gave no production at all. There was a significant difference $(p<0.05)$ in the yield from cornhusk while there was no significance different $(p>0.05)$ between the yield obtained on combination substrate and sawdust (Table 2). The total period of cultivation was observed to be between 20-60 days.

The maximum biological efficiency of $67.03 \%$ was obtained on cornhusk while the least biological efficiency of $16.23 \%$ was recorded on sawdust (Table 3).

In this study, we compared three different agricultural wastes which are cornhusk, sawdust and banana leaves as growing substrates for the cultivation of $P$. ostreatus. Not all the substrates used in this research supported the growth of $P$. ostreatus without the addition of supplements such as rice bran and wheat bran. The substrate that supported the highest yield of $P$. ostreatus was cornhusk. The maximum growth of $P$. ostreatus on the substrates actually indicates effective bio-conversion of this waste (cornhusk). The capacity of $P$. ostreatus to break down cornhusk makes it a valuable waste control strategy. There has been an earlier report by [13] on the transformation of agricultural wastes to functional bio-products by $P$. ostreatus. The days of spawn running to harvesting were found to be different as some of the substrates took longer periods than others. The duration ranged from $60-85$ days. Earlier study by [14], reported that it took between 60-85 days to grow $P$. ostreatus, however, the substrates used were artichoke stalks and wheat straw.

The development of $P$. ostreatus on agricultural wastes without adding any supplement to aid the growth was found to be best on cornhusk which has not been reported on any marketable level in Nigeria further suggest that the usage of this substrate if investigated on profitable amount by mushroom growers will probably offer more benefit for production of food, making mushrooms more available and reducing the environmental burden of agricultural wastes and increasing farmers' livelihoods as the choice of substrates is increased [15 and 16]. The use of cornhusk as a substrate for cultivating oyster mushroom can also reduce air pollution linked with burning of cornhusk [17].

\section{CONCLUSION}

Cornhusk is the outer protective covering of an ear of maize; the chaff. It is known to be an agricultural waste as it is of no use to the environment. This study showed that apart from using sawdust which needs supplement to aid the growth of the oyster mushrooms, cornhusk when available in abundance could serve as substrate in mushroom production without the addition of any other supplement like rice bran, wheat bran and so on. 
Table1a: Phases of spawn running (in days) on cornhusk and banana leaves for Pleurotus ostreatus

\begin{tabular}{|c|c|c|c|c|c|c|c|}
\hline \multirow[t]{2}{*}{ Substrates } & \multirow[b]{2}{*}{ Days } & \multicolumn{6}{|c|}{ Mycelia Length (cm) } \\
\hline & & 5 & 10 & 15 & 20 & 25 & 30 \\
\hline $\mathrm{CH}$ & & $3.83 \pm 1.60^{a}$ & $10.00 \pm 2.00^{\text {aa }}$ & $13.00 \pm 2.65^{b}$ & $17.67 \pm 6.66^{a}$ & $19.33 \pm 5.13^{a}$ & $0.00 \pm 0.00^{a}$ \\
\hline $\mathrm{BL}$ & & $2.02 \pm 1.17^{a}$ & $4.17 \pm 1.89^{\mathrm{ab}}$ & $7.33 \pm 2.08^{\mathrm{bb}}$ & $14.83 \pm 2.02^{b}$ & $18.50 \pm 2.00^{a}$ & $19.17 \pm 1.26^{\text {аa }}$ \\
\hline
\end{tabular}

$\mathrm{CH}=$ Cornhusk, $\mathrm{BL}=$ Banana leaves. Mean $\pm \mathrm{SD}$ with different superscript on the column = significant difference $(\mathrm{p}<0.05)$

Table 1b: Phases of spawn running (in days) on combined substrates and sawdust for $P$. ostreatus

\begin{tabular}{|c|c|c|c|c|c|c|c|c|c|c|c|c|}
\hline \multirow{3}{*}{ Days } & \multicolumn{12}{|c|}{ Mycelia Length (cm) } \\
\hline & 5 & 10 & 15 & 20 & 25 & 30 & 35 & 40 & 45 & 50 & 55 & 60 \\
\hline & & & & & & & & & & & & \\
\hline CB & $\begin{array}{l}0.00 \pm \\
0.00^{\mathrm{a}}\end{array}$ & $\begin{array}{l}0.00 \pm \\
0.00^{\mathrm{a}}\end{array}$ & $\begin{array}{l}4.5 \pm \\
0.38^{a}\end{array}$ & $\begin{array}{l}9.30 \pm 0 \\
.48^{\mathrm{a}}\end{array}$ & $\begin{array}{l}15.0 \\
0 \pm 1.2 \\
1^{a}\end{array}$ & $\begin{array}{l}16.0 \\
0 \pm 1 \\
24^{a}\end{array}$ & $\begin{array}{l}18.50 \\
\pm 15.0 \\
{ }^{2} 0\end{array}$ & $\begin{array}{l}15.00 \\
\pm 0.00 \\
a\end{array}$ & $\begin{array}{l}0.00 \\
\pm 0.0 \\
\mathrm{a}\end{array}$ & $\begin{array}{l}0.00 \\
\pm 0.0 \\
a\end{array}$ & $\begin{array}{l}0.00 \\
\pm 0.0 \\
a\end{array}$ & $\begin{array}{l}0.00 \pm \\
0.00^{\mathrm{a}}\end{array}$ \\
\hline SD & $\begin{array}{l}0.00 \pm \\
0.00^{\mathrm{a}}\end{array}$ & $\begin{array}{l}0.00 \pm \\
0.00^{\mathrm{a}}\end{array}$ & $\begin{array}{l}0.00 \pm \\
0.00^{\mathrm{b}}\end{array}$ & $\begin{array}{l}0.00 \pm 0 \\
.00^{\mathrm{b}}\end{array}$ & $\begin{array}{l}0.00 \pm \\
0.00^{\mathrm{b}}\end{array}$ & $\begin{array}{l}0.00 \\
\pm 0.0 \\
0^{\mathrm{b}}\end{array}$ & $\begin{array}{l}0.00 \pm \\
0.00^{\mathrm{b}}\end{array}$ & $\begin{array}{l}5.33 \pm \\
0.29^{\mathrm{b}}\end{array}$ & $\begin{array}{l}14.0 \\
0 \pm 1 \\
73^{b}\end{array}$ & $\begin{array}{l}15.0 \\
\pm 0.0 \\
0^{\mathrm{b}}\end{array}$ & $\begin{array}{l}19.0 \\
0 \pm 0 . \\
87^{b}\end{array}$ & $\begin{array}{r}22.00 \\
\pm 0.00\end{array}$ \\
\hline
\end{tabular}

$\mathrm{CB}=$ Combined substrates, $\mathrm{SD}=$ Sawdust. Mean $\pm \mathrm{SD}$ with different superscript on the column $=$ significant difference $(p<0.05)$

Table 2: Total yield of $P$. ostreatus on different substrates

\begin{tabular}{ll}
\hline Substrate & $\begin{array}{l}\text { Average } \\
\text { Yield in } \\
\text { Flush }(\mathrm{g})\end{array}$ \\
\hline Sawdust & $22.30 \pm 0.00^{\mathrm{a}}$ \\
Cornhusk & $33.53 \pm 13.70^{\mathrm{b}}$ \\
Combination & $23.00 \pm 0.00^{\mathrm{a}}$
\end{tabular}

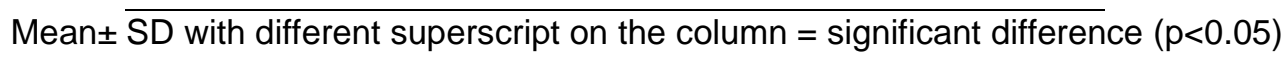


Table 3: Biological Efficiency of $\boldsymbol{P}$. ostreatus on different substrates

\begin{tabular}{lll}
\hline Substrates & $\begin{array}{l}\text { Fresh Weight of Mushroom } \\
(\mathrm{g})\end{array}$ & $\begin{array}{l}\text { Biological Efficiency } \\
(\%)\end{array}$ \\
\hline Sawdust & 22.30 & 16.23 \\
Cornhusk & 92.10 & 67.03 \\
Combination & 23.00 & 16.74 \\
Total & $\mathbf{1 3 7 . 4 0}$ & $\mathbf{1 0 0}$ \\
\hline
\end{tabular}

\section{ACKNOWLEDGEMENTS}

The authors acknowledge with thanks the contributions of Mrs. Khadijat Adedeji, CEO of Prudent Farm Organics, Ikorodu to the success of this research.

\section{COMPETING INTERESTS}

The authors declare that there are no competing interests with anyone in this research work and manuscript.

\section{AUTHORS' CONTRIBUTIONS}

TSE, AOO and OAO designed the study. $A O O$ and AAS carried out experimental analyses. TSE and AOO managed the literature searches. AOO wrote the first draft of the manuscript. All authors reviewed the final manuscript before submission.

\section{REFERENCES}

1. Chang, S.T. World production of cultivated and medicinal mushrooms in 1997 with emphasis on Lentinus edodes. International Journal of Medicinal Mushrooms. 1999;1:292-300.

2. Royse, D.J. Influence of spawn rate and commercial delayed release of nutrient levels on Pleurotus conocopiae yield, size and time of production. Applied Microbiology and Biotechnology. 2002;17:191-200.

3. Das, N. and Mukherjee, M. Cultivation of Pleurotus ostreatus on weed plants. Bioresource Technology. 2007;98:2723-2726.

4. Eswaran, A. and Ramabadran, R. Studies on some physiological, cultura and post harvest aspects of oyster mushroom (Pleurotus ostreatus). Tropical Agricultural Research. 2000;12:360-374.

5. Bahl, N. Handbook on Mushrooms. Oxford and IBH Publishing Co. Pvt Ltd. 1998;15-40pp.

6. Eger, G., Eden, G. and Wissig, E. Pleurotus ostreatus breeding potential of a new cultivated mushroom. Theoretical and Applied Genetics. 1976;47:155-163.

7. Adejoye, O.D., Adebayo-Tayo, B.C., Ogunjobi, A.A, Olaoye, O.A and Fadahunsi, F.I. Effect of carbon, nitrogen and mineral sources on growth of Pleurotus florida, a Nigerian edible mushroom. African Journal of Biotechnology. 2006;5:1355-1359.

8. Shah, Z.A., Ashraf, M. and Ishtiq, C.H. Comparative study on cultivation and yield performance of oyster mushroom (Pleurotus ostreatus) on different substrates. Pakistan Journal of Nutrition. 2004;3:158-160.

9. Amin, S.M.R., Sarker, N.C., Moonmoon, M., Khandaker, J. and Rahman, M. Officer's training manual. National Mushroom Development and Extension Centre, Savar, Dhaka, Bangladesh. 2007; p 7-17.

10. Zadrazil, F. and Brunnert, F. Investigation of Physical Parameters Important for the solid state fermentation of straw by white rot fungi. Europe Journal of Applied Microbiology Biotechnology. 1981;11:183-188.

11. Nasir, A.K., Ajmal, M., Inam, U.H. and Nazir, J. Impact of Sawdust using various woods for effective cultivation of Oyster Mushroom. Pakistan Journal of Botany. 2012;44:399-402.

12. Chang, S.T., Lau, O.W. and Cho, K.Y. The cultivation and nutritive value of Pleurotus sajor-caju. European Journal of Applied Microbiology and Biotechnology. 1981;12:5862.

13. Akinyele, B.J., Olaniyi, O.O. and Arotupin, D.J. Bioconversion of selected agricultural wastes and associated enzymes by Volvariella volvacea, an edible mushroom. Research Journal of Microbiology. 2011;6:63-70.

14. Earnshaw, D.M., Dlamini, B.E. and Masarirambi, M.T. Growth and yield of Oyster Mushroom ( $P$. ostreatus) grown on different substrates amended with varying levels of wheat bran. International Journal of Life Sciences. 2012;1(4):111-117.

15. Sanchez, A., Ysunza, F., Beltran-Gracia, M.J. and Esqueda, M. Biodegradation of viticulture wastes by Pleurotus. A source of microbial and human food and its potential use in animal feeding. Journal of Agricultural and Food Chemistry. 2002;50:2537-2542.

16. Chitamba, J., Dube, J., Chiotas, W.M. and Handiseni M. Evaluation of substrate productivity and market quality of Oyster Mushroom (Pleurotus ostreatus) grown on 
different substrates. International Journal of Agricultural Research. 2012;7:100-106.

17. Ukoima, H.N., Ogbonnaya, I.O., Arikpo, G.E. and Ikpe, F.N. Cultivation of mushroom (Volvariella volvacea) on various farm wastes in Obubra Local Government of Cross River
State, Nigeria. Pakistan Journal of Nutrition. 2009;8:1059-1061. 